\title{
Kinetic Studies on Disappearance Pattern of Sulfaquinoxaline trom the Organs and Eggs of Chickens
}

\author{
Minoru YoshidA and Norihide NoSE* \\ National Institute of Animal Health, \\ Yatabe, Tsukuba, Ibaraki 305, Japan \\ * Saitama Prefectural Institute of Public Health, \\ Kamiokubo-higashi, Urawa 338, Japan
}

Data on residue of sulfaquinoxaline (SQ) in the organs and eggs of laying hens and broilers after withdrawal of SQ in feed or drinking water have been reported by RIGHTER et al. ${ }^{1)}$ and Nose et $a l .{ }^{2)}$. The latter reported results of kinetic studies on parts of their data, assuming a one-compartment model. In the model, the relationship between days after the withdrawal of the $\operatorname{drug}(\mathrm{t})$ and the residual drug (ppm) in the organs (y) was exponential as described by Equation 1, which was transformed into a linear regression as shown by Equation 2,

$$
\begin{aligned}
& \mathrm{y}=\mathrm{Ae}^{-\mathrm{ct}} \ldots \ldots \\
& \log \mathrm{y}=\mathrm{a}+\mathrm{bt}
\end{aligned}
$$

where, $\mathrm{A}$ is an initial concentration of the residual drug, c corresponds the speed of the disappearance of the drug, $a$ is $\log A$ and $b$ is $-c \cdot \operatorname{loge}$.

Biological half life of the drug, $T_{1 / 2}$, can be calculated from the regression coefficient $b$, as $T_{1 / 2}=-\log 2 / b$. The half life is charactristic to the drug, therefore, the value is supposed to be constant for a certain drug, independently of the organs of the chick.

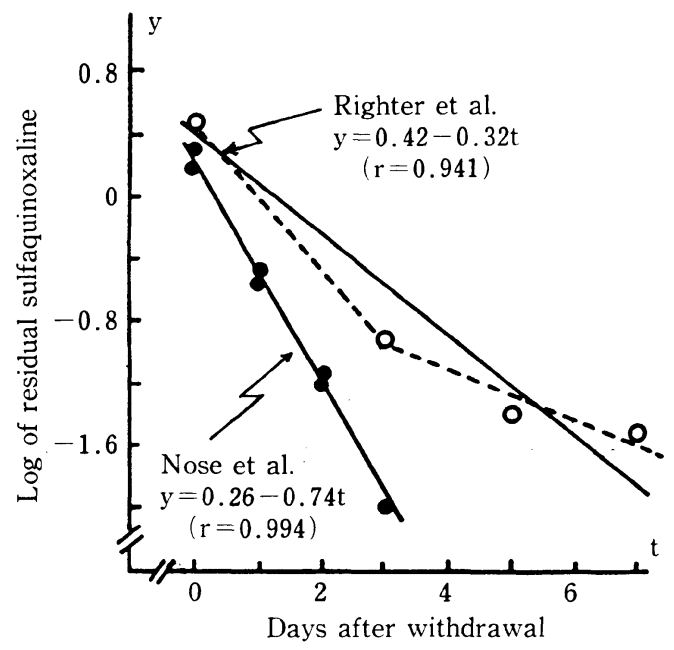

Fig. 1. Disappearance of sulfaquinoxaline from the muscle of broiler. 
Covariance analyses of the data reported by Righter et al. ${ }^{1)}$ and Nose et al. ${ }^{2)}$ revealed that the disappearance patterns of $S Q$ in these two studies were different. Biological half life of SQ estimated from the data reported by NoSE et al. ${ }^{2}$ ' was significantly shorter than that from the data of RIGHTER et al. ${ }^{1)}$. To understand this discrepancy, disappearnce of SQ from the muscle of the broiler administered SQ in feed are presented in Fig. 1. Linear regression described by Equation 2 could be applied to both of the pattern. However, as shown in Fig. 1, the slopes of the lines were significantly different, suggesting firster disappearance in the data reported by Nose et al. ${ }^{2)}$ than that reported by Righter et al. ${ }^{11}$ As shown in Fig. 1, a broken dotted line was looked more suitable to describe the data presented by Righter et $a l^{11}$. than the straight line did. This type of the disappearance pattern can be well described assuming a two-compartment model. In the model, the pattern can be divided into 2 stages, i.e., initial stage, in which the residual drug disappeares rapidly with short biological half life, and latter stage, in which the drug disappears slowly with long half life. The pattern can be described by Equation 3,

$$
\mathrm{y}=\mathrm{A}_{1} \mathrm{e}^{-\mathrm{ct}}{ }_{1}+\mathrm{A}_{2} \mathrm{e}^{-\mathrm{ct} \mathrm{t}_{2}} \text {. }
$$

where, $A_{1}$ and $c_{1}$ are coefficients indicating an initial concentration of the residual drug and a speed of disappearance in the initial stage, and $A_{2}$ and $c_{2}$ are those in the latter stage.

In this paper, results of kinetic studies on the data of two groups of researchers were presented.

\section{Materials and Methods}

Brief description of experiments in the papers:

In the experiments reported by RIGHTER et $a l^{1}$. , laying hens were fed a diet containing $0.05 \%(500 \mathrm{ppm})$ of SQ of either in pure form or in a $40 \%$ premix for 12 days intermittently, and meat-type chicks of 5-week-old were fed a diet containing $0.025 \%$ (250 ppm) of SQ or given drinking water containing $0.025 \%$ of SQ for 14 days. After the withdrawal of SQ, the hens and chicks were sacrificed at $0,3,5$, and 7 days for chemical analysis of $\mathrm{SQ}$ in the muscle, liver, kidney, fat, and skin. The eggs were collected at $0,3,4$, and 5 days and SQ content in the egg whites and yolks was determined separately.

In the experiments reported by Nose et al. ${ }^{2}$, meat-type chicks of 6-week-old were fed a diet containing $60 \mathrm{ppm}$ of SQ in a premix supplying $100 \mathrm{ppm}$ of amprolium and $5 \mathrm{ppm}$ of ethopabate simultaneously for 6 weeks, and laying hens were fed a diet containing the same level of SQ in the premix for 14 days. The chicks were sacrificed at $0,1,2,3$, and 5 days after the withdrawal of the drug for chemical analyses of SQ content in the liver, kidney, blood, spleen, gizzard, heart, muscles of thigh and breast, and fat. All of the eggs laid during the medicated feeding and 14 days after the withdrawal were collected for chemical analysis.

Statistical analyses:

In the first step of statistical analyses, logarithm of the data of each organ shown by Righter et al. ${ }^{1}$ and Nose et al. ${ }^{2)}$ were analyzed for linear regression ${ }^{3)}$ individually, assuming the one-compartment model. Then, they were combined for covariance analyses ${ }^{3)}$ to examine the differences among the slopes and among the adjusted means. The means of the residual SQ in the organs of the hens given SQ in the pure form and in the $40 \%$ pre- 
mix reported by Righter et al. ${ }^{1)}$ were treated as duplicated estimations at each day.

In the second step, all of the data except those of the eggs reported by Nose et al.2) were combined and analysed assuming the two-compartment model. A computer program described previously ${ }^{4}$ was used in the analyses. In the program, common coefficients of $c_{1}$ and $c_{2}$ applicable to all of the data are simulated by repeated calculation until no meaningful change in the estimates is observed. Furthermore, a lag of the initiation of disappearance of the drug from a certain organ, which is usually zero since the residue of most of the drugs starts to disappear soon after the withdrawal of the drug, can be estimated in this program if necessary. Then, constants, $A_{1}$ and $A_{2}$, for the individual organ were estimated by least square with common $c_{1}$ and $c_{2}$. Standard deviation of the difference between the observed and estimated data was calculated for individual organs to evaluate the fitness of the model, and also all of the deviations were pooled to obtain more reliable deviation with larger degrees of freedom.

In the third step, the data were grouped in 4 . The first group was composed of the data of the edible organs and the blood, except those of the kidney, fat and skin. The second group was those of the kidney and the third group those of the fat and skin.

The fourth group was those of the whole egg. The first and the third group were analysed assuming the two-compartment moded in which the initial stage was for 2 days. The second group was analyzed similarly, but supposing that the disappearance of the drug be initiated at a certain days after the withdrawal of the drug. The fourth group was analysed similarly assuming the two-compartment model in which the initial stage was one day.

An electronic computer ACOS 800 II of the Computing Center for Research in Agriculture, Forestry and Fishery was used in the analyses with programs written by the author.

\section{Results}

Results of covariance analysis of all of the data ${ }^{1,2)}$ assuming the one-compartment model are presented in Table 1. Highly significant "difference among the slopes" indicated that regression lines corresponding to each of the organs were not parallel, and therefore, the one-compartment model was not effective to describe the disappearance pattern as a whole.

In the second step of the statistical analyses, it was revealed that common coefficients, $c_{1}$ and $c_{2}$, applicable to all of the data were not simulated even after 19 runs of the repeated calculation. Instead of constant values, a set of values appeared repeatedly, or rather circulatingly after 8 runs as shown in Table 2 . The findings suggested that single two-

Table 1. Covariance analysis of disappearance data of sulfaquinoxaline assuming one-compartment model

\begin{tabular}{lccc}
\hline Factor & $\begin{array}{c}\text { Degrees of } \\
\text { freedom }\end{array}$ & $\begin{array}{c}\text { Sum of } \\
\text { squares }\end{array}$ & $\begin{array}{c}\text { Mean } \\
\text { square }\end{array}$ \\
\hline Total regression & 119 & 43.4207 & \\
Among adjusted means & 23 & 32.2444 & $1.4019 * * 1$ ) \\
Pooled regression & 96 & 11.1763 & 0.1164 \\
Difference among slopes & 23 & 5.4812 & $0.2383 * *$ \\
Pooled residual & 73 & 5.6951 & 0.0780 \\
\hline 1) **Singificant at 1\% level. & & & \\
\hline
\end{tabular}


Japan. Poultry Sci., 22 (5), 1985

Table 2. Simulation of common coefficient $\mathrm{c}$ applicable to all the data

\begin{tabular}{rccc}
\hline Run & $-c_{1} \cdot \operatorname{loge}$ & $-c_{2} \cdot \operatorname{loge}$ & $V^{11}$ \\
\hline 1 & 0.583 & 0.218 & 1.864 \\
2 & 0.653 & 0.218 & 0.616 \\
3 & 0.653 & 0.177 & 0.720 \\
4 & 0.631 & 0.177 & 0.553 \\
5 & 0.631 & 0.196 & 0.590 \\
6 & 0.639 & 0.196 & 0.589 \\
7 & 0.639 & 0.175 & 0.616 \\
8 & 0.629 & 0.175 & 0.549 \\
9 & 0.629 & 0.196 & 0.591 \\
10 & 0.639 & 0.196 & 0.588 \\
11 & 0.639 & 0.175 & 0.615 \\
12 & 0.629 & 0.175 & 0.549 \\
13 & 0.629 & 0.196 & 0.592 \\
14 & 0.639 & 0.196 & 0.588 \\
15 & 0.639 & 0.175 & 0.615 \\
16 & 0.629 & 0.175 & 0.549 \\
17 & 0.629 & 0.196 & 0.591 \\
18 & 0.639 & 0.196 & 0.588 \\
19 & 0.639 & 0.175 & 0.615 \\
\hline 19 & 0 & &
\end{tabular}

1) Square of deviation from regression.

compartment model can not be applicable to describe the disappearance pattern of all of the organs. Examination of the results in detail revealed that some of the regression coefficient, $\mathrm{b}$, in the latter stage of the fat and the skin, which should be negative, were close to zero or positive, suggesting that the residual drug disappeared very slowly or was increasing.

Therefore, the data except those of the fat and skin were re-analyzed. Again, not only no constant values were obtained, but also a set of the values appeared circulatingly. Examination of the results in detail revealed that standard deviation of the difference between

Table 3. Simulation of common coefficient $\mathrm{c}$ applicable to the data of the first group ${ }^{1)}$

\begin{tabular}{cccc}
\hline Run & $-c_{1} \cdot$ loge & $-c_{2} \cdot$ loge & $\mathrm{V}^{2)}$ \\
\hline 1 & 0.618 & 0.236 & 0.349 \\
2 & 0.704 & 0.236 & 0.062 \\
3 & 0.704 & 0.216 & 0.071 \\
4 & 0.683 & 0.216 & 0.047 \\
5 & 0.683 & 0.211 & 0.049 \\
6 & 0.679 & 0.211 & 0.045 \\
7 & 0.679 & 0.210 & 0.046 \\
8 & 0.677 & 0.210 & 0.045 \\
9 & 0.677 & 0.209 & 0.045 \\
10 & 0.677 & 0.209 & 0.045 \\
11 & 0.677 & 0.209 & 0.045 \\
\hline
\end{tabular}

1) Eddible parts except the kidney, fat, and skin.

2) Square of deviation from regression. 
the observed and estimated values in the kidney reported by Nose et al. ${ }^{2}$ was extremely large, being 3.1817 which was highly significant $(\mathrm{P}<0.01)$ compared with the pooled standard deviation of 0.0153 with degrees of freedom of 56 . This large standard deviation was mainly due to the large difference between the observed and estimated values at 0 day after the withdrawal of the drug. The findings suggested that a lag should be taken into consideration to describe the disappearance pattern from the kidney.

Change in common coefficients, $c_{1}$ and $c_{2}$, and the deviation from the regression in covariance analyses of the data of the first group are presented in Table 3 . In the Table 3 , not the coefficients themselves, but $-c \cdot \operatorname{loge}$, which is $\mathrm{b}$ in Equation 2 , are presented. As shown in Table 3, constant coefficients were obtained after 9 runs, and the following Equation 4 with common $c_{1}$ and $c_{2}$ was found fit to describe the disappearance pattern,

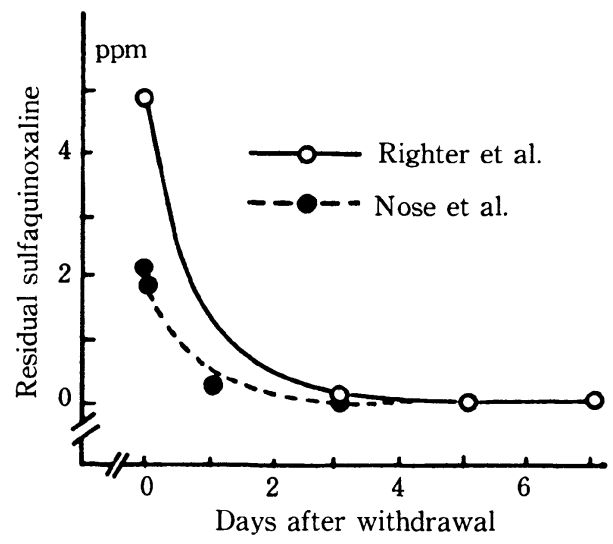

Fig. 2. Disappearance pattern of sulfaquinoxaline from the muscle of broiler.

Table 4. Comparison of squares of deviation from regression of the residue in the kidney at various lags

\begin{tabular}{rrrrr}
\hline Run & \multicolumn{1}{c}{ Lag } & 0.2 & 0.3 & 0.4 days \\
\hline 1 & 18.523 & 0.823 & 1.890 & 2.674 \\
2 & 6.406 & 0.629 & 1.627 & 2.353 \\
3 & 2.576 & 2.709 & 1.180 & 2.016 \\
4 & 0.497 & 0.849 & 1.546 & 2.275 \\
5 & 3.555 & 1.269 & 1.379 & 2.177 \\
6 & 0.415 & 0.924 & 1.502 & 2.241 \\
7 & 4.047 & 1.033 & 1.461 & 2.223 \\
8 & 0.423 & 0.945 & 1.491 & 2.234 \\
9 & 4.122 & 0.976 & 1.481 & 2.231 \\
10 & 0.409 & 0.951 & 1.488 & 2.233 \\
11 & 3.889 & 0.960 & 1.486 & 2.233 \\
12 & 0.424 & 0.952 & 1.487 & 2.233 \\
13 & 4.186 & 0.955 & 1.487 & 2.233 \\
14 & 0.409 & 0.953 & 1.487 & 2.233 \\
15 & 3.867 & 0.954 & 1.487 & 2.233 \\
\hline
\end{tabular}


where $A_{1}$ and $A_{2}$ are initial values in each of the organs, which varies depending on hte concentration of the drug in the feed or water, on the length of the medication, and on various other factors. As an example, the disappearance patterns from the muscle of the broiler reported by Righter et al. ${ }^{1)}$ and by Nose et al. ${ }^{2)}$ are presented in Fig. 2.

Among the results of the analyses of the data in the kidney, the deviation from regression at various lags are shown in Table 4. With lag shorter than 0.2 days, no constant value was simulated. With lag of 0.3 days, a constant value was obtained after 12 runs. With lag longer than 0.4 days, a constant value was obtained, but the deviation from the regression was significantly larger than that at the lag of 0.3 days. The following Equation 5 was found fit to describe the disappearance pattern from the kidney,

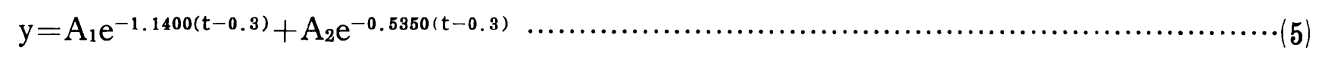

where, $(t-0.3)$ shold be assumed to be zero, when it is negative. As an example, the disappearance patterns from the kidney of the broiler are shown in Fig. 3.

From the combined analyses of the data of the fat and skin, Equation 6 was found fit to describe the relationship,

$$
\mathrm{y}=\mathrm{A}_{1} \mathrm{e}^{-1.3593 \mathrm{t}}+\mathrm{A}_{2} \mathrm{e}^{-0.3611 \mathrm{t}}
$$

As an example, the disappearance patterns from the adipose tissue of the broiler are presented in Fig. 4.

From the SQ residue in the whole egg reported by Nose et al. ${ }^{2}$, following Equation 7 was found fit to describe the disappearance pattern.

$$
\mathrm{y}=0.937 \mathrm{e}^{-3.4431 \mathrm{t}}+0.163 \mathrm{e}^{-0.2261 \mathrm{t}}
$$

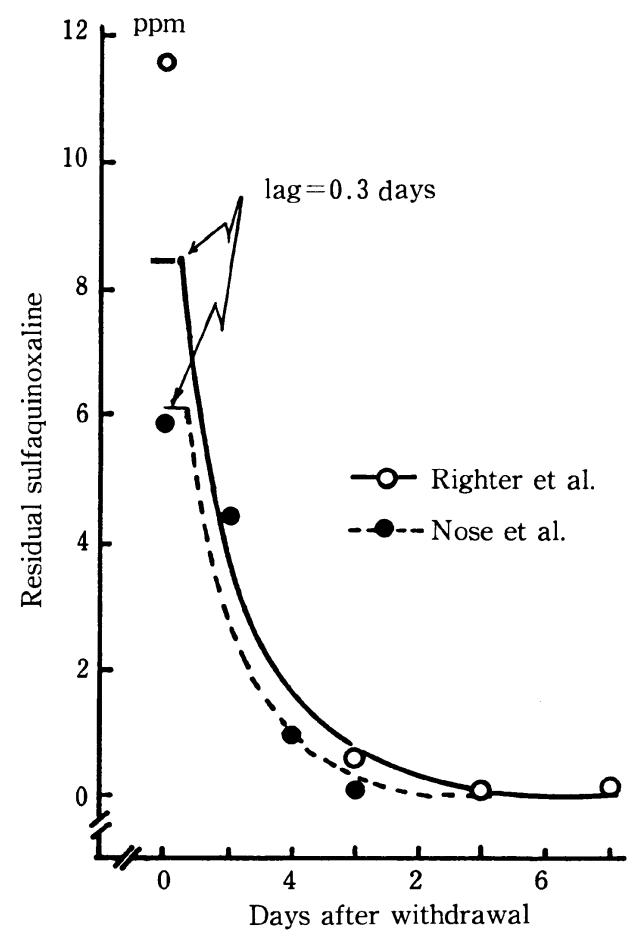

Fig. 3. Disappearance pattern of sulfaquinoxaline from the kidney of broiler. 


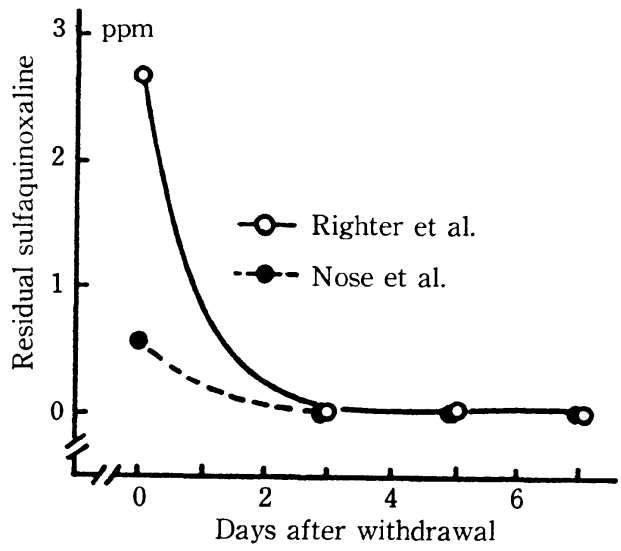

Fig. 4. Disappearance pattern of sulfaquinoxaline from the adipose tissue of broiler.

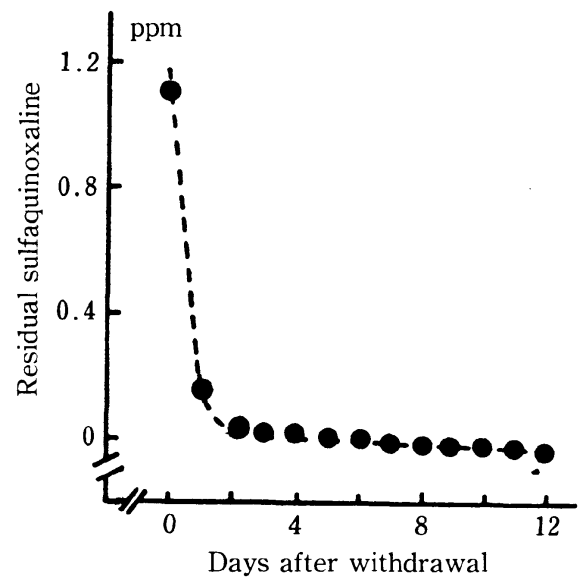

Fig. 5. Disappearance pattern of sulfaquinoxaline from the whole egg (Nose et al.)

Table 5. Biological half lives from various organs (days)

\begin{tabular}{lcc}
\hline Stage & Mean & $95 \%$ interval \\
\hline $\begin{array}{l}\text { 1st group }{ }^{1)} \\
\text { initial }\end{array}$ & 0.45 & $0.50-0.40$ \\
latter & 1.44 & $1.88-1.17$ \\
Kidney: & & \\
$\quad$ initial & 0.61 & -0.13 \\
altter & 1.23 & $2.53-0.87$ \\
Fat and Skin: & & $3.50-1.32$ \\
$\quad$ initial & 0.51 & \\
latter & 1.92 & \\
Whole egg: & & $3.86-2.54$ \\
initial & 0.2 & \\
latter & 3.07 &
\end{tabular}

1) Eddible parts except the kidney, fat and skin. 
As shown in Fig. 5, a small amount of SQ less than $0.01 \mathrm{ppm}$ will be detected from the whole egg for a long time, even at 12 days after the withdrawal of the drug.

In Table 5, biological half lives of SQ from 4 groups of the organs are presented. $\mathrm{Be}$ cause of the smallness of the sample size, 95\% fiducial upper limits for the half lives in the initial stage from the kidney and from the fat and skin were not calculated. The fiducial interval was not calculated for the half life in the initial stage from the egg, because only 2 data, for 0 and 1 days after the withdrawal, were available in the initial stage.

The biological half life of SQ from the whole egg in the latter stage was significantly longer than those from the organs of the first group and from the kidney. If the sample size be large enough, the biological half life from the egg in the latter stage will be confirmed to be longer than that from the fat and skin.

In Table 6, coefficients, $A_{1}$ and $A_{2}$, which correspond to the initial concentration of $\mathrm{SQ}$ in the various organs in the initial and latter stages, respectively, are presented. Since the dose of SQ administered by Righter et al. ${ }^{1)}$ was much higher than that by Nose et al. ${ }^{2}$, the cefficients estimated from the data of the former in a certain organ were larger than those in the corresponding organ of the latter.

Table 6. Coefficients $A_{1}$ and $A_{2}$ for sulfaquinoxaline

\begin{tabular}{|c|c|c|c|c|c|}
\hline Bird & Routs & Organ & Ref. $^{11}$ & $A_{1}$ & $\mathrm{~A}_{2}$ \\
\hline \multirow[t]{2}{*}{ Laying hen } & \multirow[t]{2}{*}{ Feed } & Breast muscle & 1 & $\begin{array}{l}\text { ppm } \\
8.10\end{array}$ & $\begin{array}{l}\text { ppm } \\
0.50\end{array}$ \\
\hline & & Liver & 1 & 6.84 & 1.99 \\
\hline \multirow[t]{2}{*}{ Broiler } & \multirow[t]{2}{*}{ Feed } & Breast muscle & 1 & 4. 40 & 0.50 \\
\hline & & Liver & 1 & 5.69 & 0.61 \\
\hline \multirow[t]{2}{*}{ Broiler } & \multirow[t]{2}{*}{ Water } & Breast muscle & 1 & 6.63 & 1.27 \\
\hline & & Liver & 1 & 3.96 & 1. 14 \\
\hline \multirow[t]{7}{*}{ Broiler } & \multirow[t]{7}{*}{ Feed } & Breast muscle & 2 & 1.46 & 0.04 \\
\hline & & Thigh muscle & 2 & 1.61 & 0.04 \\
\hline & & Liver & 2 & 2.13 & 0.35 \\
\hline & & Gizzard & 2 & 2.01 & 0.10 \\
\hline & & Spleen & 2 & 2.78 & 0.16 \\
\hline & & Heart & 2 & 4.15 & 0.10 \\
\hline & & Blood & 2 & 3.84 & 0.06 \\
\hline Laying hen & Feed & Kidney & 1 & 3.27 & 7.79 \\
\hline Broiler & Feed & Kidney & 1 & 7.35 & 1.22 \\
\hline Broiler & Water & Kidney & 1 & 8.50 & 5.24 \\
\hline Broiler & Feed & Kidney & 2 & 6. 01 & 0.32 \\
\hline \multirow[t]{2}{*}{ Laying hen } & \multirow[t]{2}{*}{ Feed } & Fat & 1 & 2.18 & 0.49 \\
\hline & & Skin & 1 & 7.77 & 1.43 \\
\hline \multirow[t]{2}{*}{ Broiler } & \multirow[t]{2}{*}{ Feed } & Fat & 1 & 2.60 & 0.10 \\
\hline & & Skin & 1 & 7.78 & 0.62 \\
\hline \multirow[t]{2}{*}{ Broiler } & \multirow[t]{2}{*}{ Water } & Fat & 1 & 4.88 & 0.12 \\
\hline & & Skin & 1 & 17.26 & 1.74 \\
\hline Broiler & Feed & Fat & 2 & 0.59 & 0.03 \\
\hline
\end{tabular}

1) indicating No. of the literature cited. 


\section{Discussion}

Apparent difference in the disappearance pattern of SQ from the organs observed in two laboratories was partly due to the fact that the disappearance pattern is different in different organs, and partly due to the fact that American group ${ }^{1)}$ determined the residue of SQ mainly at the latter stage, while Japanese group ${ }^{2)}$ did mainly at the initial stage. It is impressive that the data of two groups, which looked like so different each other at the first comparison, can be described well assuming one model of two-compartment. Difference in the condition of the administration such as the form of the drug, i.e., the pure form, the $40 \%$ premix or the mixture of three drugs, i.e., amprolium, ethopabate and SQ, the route of administration, i.e., feed and drinking water, made no difference in the pattern of disappearance and biological half life.

Supposing that $\mathrm{SQ}$ in the organs be sent to the kidney and excreted into the urine, the concentration of the durg in the kidney may be kept constant or even increasing within a certain short time after the withdrawal of the drug. The time lag shown in Fig. 4 indicated that the kidney works most likely as a main route of the excretion of SQ. To confirm this supposition, further study will be required on the SQ residue in the kidney soon after the withdrawal of the drug.

In the two-compartment model, the drug is stored in a certain place of the body from which the drug is released slowly in the latter stage. The storage place for tetracyclines (TC) was suspected to be the bone ${ }^{5)}$ and that for polychlorinated biphenyl (PCB) was the adipose tissue ${ }^{6 \sim 8)}$. As pointed out already by RIGHTER et al. ${ }^{1}$, the adipose tissue or fatcontaining cells in the sebaceous gland of the skin was first suspected to be the storage place, because the disappearance of SQ from the tissues was slower than those from the other organs. This assumption was not confirmed. If the adipose tissue be the storaeg place, then the disappearance pattern of SQ from the adipose tissue could be explained well assuming a one-compartment model as the pattern of TC from the bone ${ }^{5)}$ and PCB from the adipose tissue ${ }^{6-8)}$ did. To the data on the residual SQ in the adipose tissue reported by two groups of the researchers ${ }^{1,2)}$, it was confirmed that the two-compartment model given by Equation 6 was best fit to describe the pattern. Further studies are certainly required to find the storage place for SQ.

The egg yolk grows for about 10 days before ovulation, while the egg white was secreted for about 24 hours. Therefore, the disappearance pattern from the egg yolk is quite different from the pattern from the egg white as discussed with tylosine ${ }^{9)}$, and the pattern from the whole egg can be described by the one-compartment model ${ }^{9}$. However, the onecompartment model was not fit to describe the disappearance pattern of SQ from the whole egg. One of the reaseon was a drustic decrease of residual SQ at the first day as shown in Fig. 5., and another reason was long tailing of small amount of SQ.

As shown in Fig. 5, very small amount of SQ less than $10 \mathrm{ppb}$ was found in the egg even at 12 days after the withdrawal of SQ from the feed. Also, in the edible parts(Fig. 2) and the adipose tissue (Fig. 4), SQ was suspected to be detected for a long time after the withdrawal. This pharmaco-kinetic charcater of SQ should be kept in mind in the therapeutic use of this drug. 


\section{Summary}

Kinetic studies of the residue of sulfaquinoxaline (SQ) in the organs of broilers and laying hens and in the eggs after withdrawal of the drug from either feed or drinking water revealed that the organs could be grouped into 3 , based on the disappearance pattern of SQ.

The pattern from the edible organs and the blood, except the kidney, fat and skin, could be explained assuming a two-compartment model, in which a part of the drug administered was stored in a certain place in the body and released slowly after the initial rapid decrease of residural SQ from the organs. The pattern could be described by the following equation,

$$
\mathrm{y}=\mathrm{A}_{1} \mathrm{e}^{-1.558 \mathrm{t} t}+\mathrm{A}_{2} \mathrm{e}^{-0.4816 \mathrm{t}}
$$

where $A_{1}$ and $A_{2}$ are initial concentrations of $S Q$ in the initial and the latter stages, respectively.

The pattern from the kidney could be explained assuming a two-compartment model with a time lag of 0.3 days, and the following equation was found fit to describe the disappearnce pattern from the kidney.

$$
\mathrm{y}=\mathrm{A}_{1} \mathrm{e}^{-1.1400(\mathrm{t}-0.3)}+\mathrm{A}_{2} \mathrm{e}^{-0.5350(\mathrm{t}-0.3)}
$$

It was suggested that the drug released from the body were sent to the kidney and excreted into the urine. Thus, the kidney was supposed to work as a main excit of the SQ excretion.

The disappearance pattern from the adipose tissue could be well described by the following equation, suggesting that the adipose tissue may not be the storage place for $\mathrm{SQ}$.

$\mathrm{y}=\mathrm{A}_{1} \mathrm{e}^{-1.3593 \mathrm{t}}+\mathrm{A}_{2} \mathrm{e}^{-0.3611 \mathrm{t}}$

The disappearance pattern from the whole egg could be described by the following equation, assuming a two-compartment model.

$$
\mathrm{y}=0.937 \mathrm{e}^{-3.4431 \mathrm{t}}+0.163 \mathrm{e}^{-0.2261 \mathrm{t}}
$$

Biological half lives from the edible parts except the kidney and adipose tissue in the initial and latter stages were estimated to be 0.45 and 1.44 days, respectively. Those from the whole eggs were estimated to be 0.20 and 3.07 days, respectively.

\section{Reference}

1) Righter, H.F., J. M. Worthington, H. E. Zimmerman, Jr. and H. D. Mercer (1970) Tissue-residue depletion of sulfaquinoxaline in poultry, Am. J. Vet. Res., 31:1051-1054.

2) Nose, N., Y. Hoshino, Y. Kikuchi, H. Masaki, S. Horie and S. Kawauchi (1982) Residues of synthetic antibacterial feed additives in tissues and eggs of chickens (in Japanese), J. Food Hyg. Soc. Japan, 23: 246-252.

3) Yoshida, M. (1983) Design of experiments for animal husbandry (in Japanese): pp. 163-182 and 314-323, Yoken-do, Tokyo.

4) Yoshida, M. (1985) Re-estimation of coefficients describing disappearance pattern of tetracyclines from chick body, Japan. Poult. Sci., 22, 73-75.

5) Yoshida, M., H. Hoshil, S. Yonezawa, H. Nogawa, H. Yoshimura and O. Ito (1975) Disappepearance pattern of chlortetracycline from the liver, bile and tibia bone of growing chicks, ibid., 12, 238-245.

6) Fries, G.F., G.S. Marrow, JR. and C. H. Gordon (1973) Long-term studies of residue retention and excretion by cows fed a polychlorinated biphenyl (Aroclor 1254), J. Agr. Food Chem., 21, 
$117-121$.

7) Saito, S., Y. Goda, S. Nagura, S. Nagata, A. Watanabe, A. Kobayashi and M. Miyashita (1976) Transfer of polychlorinated biphenyl (PCB) into eggs and its effect on egg production and hatchability (in Japanese), Japan. Poult. Sci., 13, 86-92.

8) Goda, Y., S. Saito, S. Nagura, S. Nagata, A. Kobayashi and M. Miyashita (1980) A feeding test of polychlorinated biphenyl (PCB): Its accumulation and disapprance in hen's eggs and fat, and its effect on egg production (in Japanese), ihid., 17, 265-273.

9) Yoshida, M., D. Kubota, S. Yonezawa, H. Nakamura, R. Yamaoka and H. Yoshimura (1973) Transfer of dietray tylosin into the eggs and its residue in the liver of laying hen, ibid., 10, 2936.

\section{鷄の臓器及び卵からのサルファキノキサリンの消失に関する動態}

\section{吉 田實・能 勢 憲 英*}

家畜衛生試験場, 筑波郡谷田部町観音台 305

埼玉県衛生研究所 浦和市上大久保東 338

飼料もしくは飲水に添加して投与され, ブロイラーや 産卵鷄の蔵器及び鷄畉中に残留している+ルンァキノキ サリン(SQ) の投与中止後の消失経過を速度論的に検討 したところ，4群に区分できることが明らかとなった。

腎蔵, 皮膚, 脂肪を除く鶏肉や胿臓などの可食部扣よ び血液からの消失パターンは, SQ が体内のある部位に 眝蔵されていて前期の急速な消失経過の後に貯蔵部位か ら緩やかに放出されるといら2 区画モデルでよく説明さ れた。消失パターンは次式で示される。

$$
y=A_{1} e^{-1.5586 t}+A_{2} e^{-0.4816 t}
$$

ただし， t は休薬後の日数， $\mathrm{y}$ は SQの残留量 (ppm), $\mathrm{A}_{1}, \mathrm{~A}_{2}$ はそれぞれ前期と後期における $\mathrm{SQ}$ 残留の初期 值であって, 蔵器の種類, SQ の添加量, 投与日数等の 条件によって異なる一定值である。

腎蔵からの消失経過は, 0.3 日遅れの 2 区画モデルで 説明され，次式で示される。

$$
\boldsymbol{y}=A_{1} e^{-1.1400(t-0.3)}+A_{2} e^{-0.5350(t-0.3)}
$$

体内各㵴器から放出された SQ は腎蔵に送られて排泄さ
れるので, 消失は他の臓器より 0.3 日(約 7 時間)避れて 始まると考学ると，時間の遅れが説明できる。この知見 は，腎臓から尿への経路が SQ の主要な排泄経路となっ ていることを示唆している。

脂肪と皮膚で示されている脂肪組織からの消失経過も 2 区画モデルで説明され, 次式で示された。

$$
y=A_{1} e^{-1.3593 t}+A_{2} e^{-0.3611 t}
$$

この知見は, 脂肪組織が貯蔵部位とはなっていないこ とを示唆するが，さらにデータを蓄積して解析すること が望まれる。

鷄卵からの消失経過も次式で示される 2 区画モデルで 説明できる。

$$
y=0.937 e^{-3.4431 t}+0.163 e^{-0.2261 t}
$$

腎臓と脂肪組織を除く可食部分からの SQ の消失速度 を示吉生物学的半減期は, 前, 後期のそれぞれについ て，0.45日と 1.44 日と計算される。これに対し，鷄卵 からの消失の生物学的半減期はそそれぞれ0.20日と 3.07 日と計算される。

（家禽会誌，22，245～255，1985） 